\title{
Еколого-фізіологічна та фітопатологічна оцінка рослинного покриву м. Ковеля в умовах урбанізації
}

У статті викладено результати комплексного дослідження впливу урбогенних факторів на довкілля. Розглянуто просторову строкатість забруднення важкими металами міських грунтів з урахуванням різної потужності джерел забруднення. Досліджено негативний вплив забруднення токсичними елементами дерново-підзолистого грунту на ріст та розвиток зелених насаджень м. Ковеля. Здійснено інвентаризацію видів міських рослин і проаналізовано морфофізіологічні зміни в деревних і трав'яних рослин, їх фенологію й життєвість в умовах техногенного пресу. Обгрунтовано та рекомендовано для озеленення такі види деревних рослин, які зменшують негативний вплив полютантів на довкілля.

Ключові слова: важкі метали, урбогенні фактори, зелені насадження, акумуляція.

Постановка наукової проблеми та її значення. Технічний розвиток суспільства призвів до того, що проблеми забруднення навколишнього середовища й виживання в ньому людства вийшли на перший план актуальних питань сьогодення. Техногенний прес на довкілля зростає 3 кожним роком, а однією з його причин $є$ урбанізація. В урбоекосистемах триває накопичення невластивих для біосфери хімічних речовин - ксенобіотиків, у тому числі й важких металів, які суттєво змінюють усталену структуру та природні функції біоценозів. Обсяги й глибина масштабних досліджень техногенного забруднення біосфери важкими металами (Виноградов, 1952, 1957; Полинов, 1953; Перельман, 1975, 1989; Власюк, 1974; Ковда, 1987; Глазовская, 1967, 1989; Добровольский, 1980, 1990; Алексеенко, 2000, 2003, Чертко, 2008) зумовлені специфікою їхньої хімічної природи та екологічними впливами, які становлять велику небезпеку в разі включення цих екотоксикантів у біогеохімічні цикли, появи у водах, харчових ланцюгах і мережах, зрештою - у продуктах харчування людини. Тому виникає потреба принципової переоцінки місця цих елементів у ранговому ряду екотоксикантів. 3'ясування закономірностей забруднення важкими металами має важливе значення як для розуміння процесів, що відбуваються в природних і штучних екосистемах, так і для виконання практичних завдань з охорони довкілля в умовах урбанізації [3].

Під час вивчення аспектів адаптивних механізмів рослинних організмів до забруднення важкими металами можна виділити три головні етапи розвитку стійкості рослин до надлишку важких металів. Спочатку відбувається затримка надлишкових іонів у кореневій системі. Наступний етап зменшення активності цих іонів за допомогою їх переходу у фізіологічно інертні форми. I як наслідок - ініціація альтернативних реакцій обміну, які менш чутливі до дії важких металів. Головну роль при накопиченні важких металів кореневою системою відіграють тканини кори коріння, а в багатьох рослинних організмах спостерігається переважаюче накопичення полютантів у кореневій системі рослин, коли їх концентрація є відносно малою, а при збільшені концентрації змінюється характер розподілу елементів і максимальним вмістом характеризується вже надземна частина рослин [9].

Розрізнені дані за проблеми впливу важких металів на рослини свідчать про різний ступінь пригнічення росту й розвитку рослин залежно від індивідуальних особливостей цієї рослини. Механізм дії токсикантів маловивчений, проте можна сказати, що стійкість рослин до одного металу, зазвичай, не характеризується такою самою стійкістю до інших токсикантів. Можливо, це пов'язано 3 генетичним апаратом і може бути використано для біоіндикації та, ураховуючи здатність рослин накопичувати шкідливі речовини, - для зменшення забруднення грунтового покриву [5]. Рослини характеризуються певною вибірковою здатністю до поглинання хімічних елементів, а також вони 3 різною швидкістю пропускають через себе ці елементи й здатні сортувати їх, затримуючи одні й пропускаючи інші. Така вибіркова спроможність має велике геохімічне значення, оскільки в іiі результаті змінюється хімічний склад окремих частин літосфери [4].

Узагальнюючи шляхи надходження важких металів у рослинний організм, можна виокремити такі фактори, що впливають на їх надходження: видова різноманітність, концентрація токсикантів у грунті та форма їх надходження, тип грунту і його агрохімічні показники.

Значна кількість забруднювачів може потрапляти в рослини також 3 атмосферних випадінь фоліарним шляхом - через листя. При надходженні токсикантів із грунтового розчину певна їх

(C) Голуб В., Голуб С., 2016 
кількість затримується в кореневій системі, а при надходженні з атмосфери не існує такого бар'єру, що зумовлює безперешкодне потрапляння металів у надземну частину рослин [1].

Поглинання металів з атмосфери відбувається двома стадіями. Спочатку відбувається неметаболічне проникнення через кутикулу, яке вважається головним. Наступний етап - накопичення елементів, тобто метаболічне перенесення іонів через плазматичні мембрани й протоплазму клітин. Це явище протилежне до дії градієнта концентрації. Визначення залежності концентрації елемента в рослині від типу поглинання (кореневе чи фоліарне) становить певну проблему. Кожна рослина має свою порогову величину діючого фактора, яка залежить від іії видової або індивідуальної стійкості рослини. Зазвичай, адаптивні реакції рослин в стійких до токсикації видів відбуваються значно довше, ніж друга фаза [8].

Згідно з літературними даними перший захисний бар'єр на кордоні корінь-рослинний субстрат ефективно працює при низькому вмісті важких металів у грунті. При сильному збільшенні концентрації токсикантів захисний механізм уже не справляється з функцією обмеження надходження металу в клітину й тоді починається інтенсивне їх надходження в рослину [6].

Захисні механізми від негативного впливу важких металів у рослин мають різну природу та грунтуються як на фізіологічному, так і на молекулярному рівнях. Який механізм буде використано рослинним організмом, залежить від самого полютанта, його концентрації в навколишньому середовищі, а також від фізіологічних особливостей рослини.

Отже, дослідження урбоекосистем, які формуються внаслідок урбанізації довкілля й трансформованості природного середовища, є актуальним завданням сучасної екології. Проте в Україні дослідження щодо інтенсивності поглинання токсичних елементів грунтами та використання їх рослинами в процесі вегетації виконано переважно в глибоко трансформованих урбопромислових регіонах центру й сходу. У північно-західній частині країни, зокрема у Волинському Поліссі, ці екологічні проблеми поглиблено не вивчали. Тому на сьогодні вони гостро актуальні для захисту довкілля від забруднень та охорони природного середовища в цьому регіоні.

Мета й завдання дослідження. Мета роботи - установити рівні забруднення урбоекосистеми м. Ковеля важкими металами, з'ясувати закономірності їх міграції в системі «грунт-рослина» та особливості впливу на зелені насадження. Для досягнення поставленої мети потрібно виконати такі основні завдання: обгрунтувати актуальність проблеми техногенного забруднення та міграції екотоксикантів в умовах північно-західного Полісся й з'ясувати ймовірні загрози урбанізації та техногенезу для довкілля Волині; установити характер найпоширеніших ушкоджень деревних рослин у зеленій зоні м. Ковеля, дослідити зв'язок умісту важких металів у гумусово-елювіальному горизонті грунтів і рослинах та їхнім життєвим станом.

Методика й умови проведення досліджень. Програмою досліджень передбачено вивчення урбоекосистеми м. Ковеля, життєвості деревних рослин міста за техногенного впливу. Для визначення рівня загального забруднення рухомими формами важких металів здійснено відбір грунтових проб у приповерхневому гумусово-елювіальному горизонті міських грунтів м. Ковеля Волинської області як шарі, який є акумулятором (концентратором) важких металів й інших екотоксикантів (ДСТУ 4287.2004). Уміст важких металів у грунті та в рослинах визначали на атомно-абсорбційному спектрофотометрі С 115-1М у полум'ї ацетилен-повітря. Використовували ацетатно-амонійний буферний розчин із $\mathrm{pH} 4,8$ ( $\mathrm{Zn}$ ) та кислотну витяжку ( $\mathrm{Mn}, \mathrm{Cu}, \mathrm{Pb}, \mathrm{Zn}, \mathrm{Co}, \mathrm{Cd}$ ) у модифікації ЦІНАО. У дослідженнях рослинності застосовано номенклатуру таксонів та їх систематичне положення за С. К. Черепановим (1981). Оцінку стану деревних рослин визначали за методикою В. С. Ніколаєвського (1999). Статистичну обробку отриманих результатів проводили за допомогою програм MS Excel i Statistika 6.0.

Виклад основного матеріалу й обгрунтування отриманих результатів дослідження. При проведенні екологічного моніторингу довкілля в м. Ковелі встановлено, що головними забруднювачами атмосфери $є$ технічні транспортні засоби. Дані щодо кількості викинутих в атмосферу шкідливих речовин підтверджують сильне забруднення довкілля в м. Ковелі. Проте розв'язання проблеми його захисту неможливе без контролю за вмістом важких металів у компонентах урбоекосистеми.

В усіх пробах грунту урбоекосистеми Ковеля спостерігаємо перевищення ГДК за вмістом свинцю (табл. 1). Найбільші значення показників уздовж залізниці (перевищення в 10,5 раза), найменші - по вул. Заводській (у 2,2 раза), але й тут вони в 5,5 раза перевищують фоновий рівень (рис. 1). 
Таблиия 1

Уміст рухомих форм важких металів у грунтах (0-10 см) урбоекосистеми м. Ковеля, $⿻ 2 / \kappa 2$ ( $n=9)$

\begin{tabular}{|c|c|c|c|c|c|c|c|}
\hline \multirow{2}{*}{$\begin{array}{l}\text { № } \\
\text { 3/II }\end{array}$} & \multirow{2}{*}{ Об'єкт дослідження } & \multicolumn{6}{|c|}{ Важкі метали } \\
\hline & & $\mathbf{P b}$ & $\mathbf{C u}$ & $\mathbf{Z n}$ & Cd & Co & Mn \\
\hline 1 & Залізниця & $21,0 \pm 1,15$ & $12,0 \pm 0,87$ & $15,0 \pm 0,84$ & $0,09 \pm 0,01$ & $1,3 \pm 0,07$ & $26,0 \pm 2,69$ \\
\hline 2 & Вул. Заводська & $4,40 \pm 0,26$ & $1,90 \pm 0,16$ & $4,0 \pm 0,10$ & $0,10 \pm 0,01$ & $1,50 \pm 0,09$ & $10,0 \pm 1,87$ \\
\hline 3 & $\begin{array}{l}\text { Парк } \\
\text { iм. Т. Г. Шевченка }\end{array}$ & $6,19 \pm 0,46$ & $3,07 \pm 0,24$ & $18,0 \pm 0,81$ & $0,10 \pm 0,01$ & $1,70 \pm 0,09$ & $20,0 \pm 0,87$ \\
\hline 4 & Вул.Т. Боровця & $10,7 \pm 0,53$ & $6,20 \pm 0,44$ & $6,0 \pm 0,44$ & $0,10 \pm 0,01$ & $1,40 \pm 0,08$ & $17,0 \pm 1,67$ \\
\hline 5 & Район АЗС & $5,30 \pm 0,30$ & $1,90 \pm 0,12$ & $7,01 \pm 0,46$ & $0,10 \pm 0,01$ & $1,20 \pm 0,09$ & $12,2 \pm 3,67$ \\
\hline
\end{tabular}

Уміст міді найбільш перевищує ГДК в околицях залізниці (у чотири рази), у грунтах по вул. T. Боровця (у 3,1 раза), а також у приавтомагістральній смузі (в 1,6 раза). Водночас в інших точках спостереження концентрація міді в 4-6 разів перевищує фонові ділянки. Концентрація цинку, кобальту, кадмію й марганцю в грунтовому покриві Ковеля перебуває в межах ГДК. Проте кількість цинку в грунтах урбоекосистеми перевищує фонові значення від 3,33 до 15 разів. Найбільший його вміст виявлено в парку ім. Т. Г. Шевченка, біля залізниці (перевищення у 12,5 раза). Міські грунти характеризуються в 1,5-2,2 раза підвищеною, порівняно 3 фоновими ділянками, концентрацією кобальту за незначної варіабельності показника (від 1,20 до 1,80 мг/кг). Порівняння даних щодо кадмію з природним фоном показує найбільше перевищення (у 3,5 раза) для проммайданчика ВАТ «Ковельсільмаш» (вул. Т. Боровця та вул. Заводська), а також дещо менше для інших об’єктів.

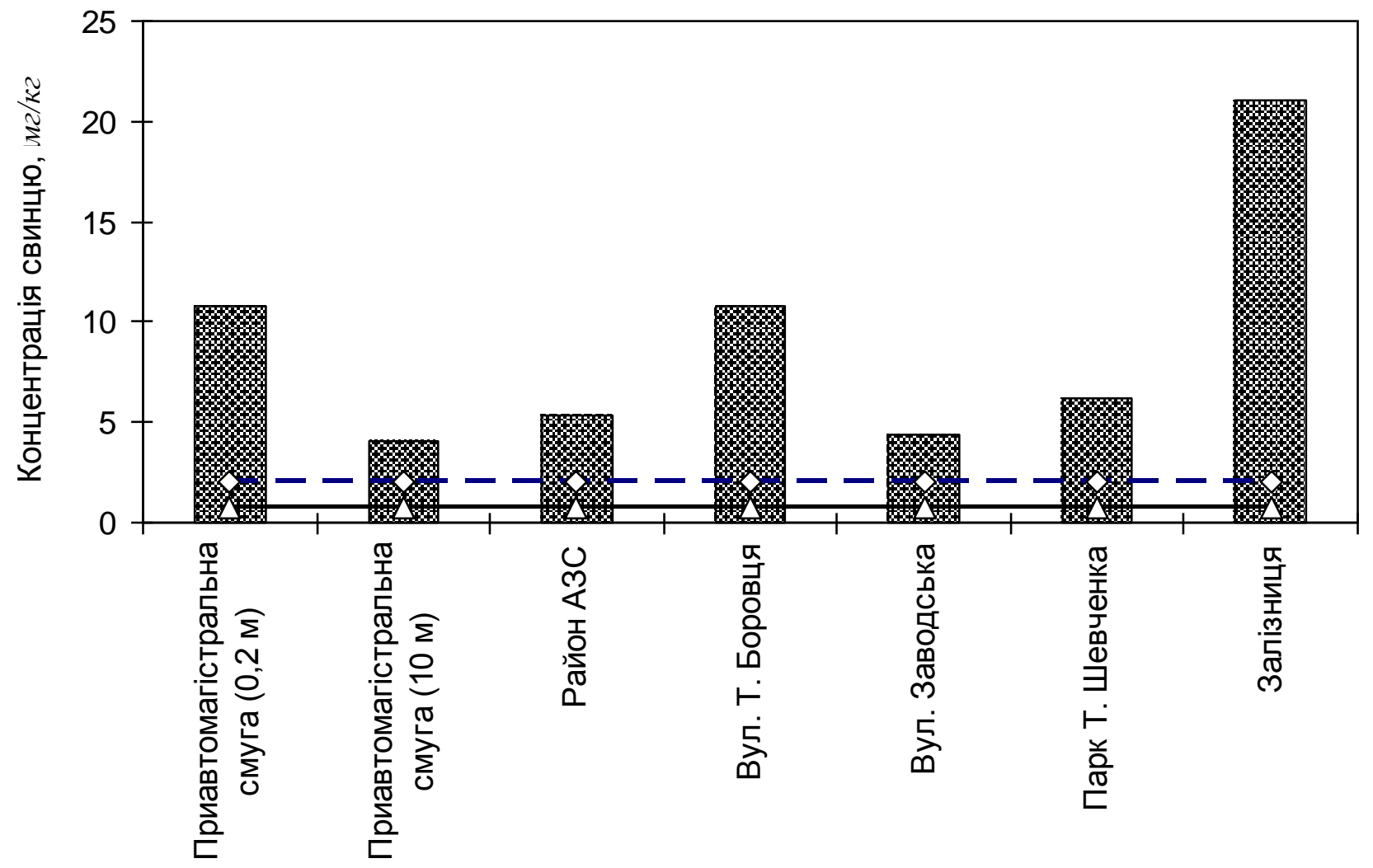

Об'єкт досліджень $-\diamond$ ГДК $\triangle$ Фон

Рис. 1. Уміст свинцю в трунтах урбоекосистеми та вздовж автомагістралі М-07 «Київ-Ковель-Ягодин» порівняно з ГДК, мг/кг 
За сукупним забрудненням важкими металами (окрім марганцю) - перевищенням фонових значень і ГДК - найбільше виділяються грунти вздовж залізничної колії на території м. Ковеля. За зменшенням ступеня забруднення досліджувані ділянки утворюють наступний ряд: залізниця > парк ім. Т. Г. Шевченка > вул. Т. Боровця > АЗС > вул. Заводська. Тому першочергових заходів із покращення якості довкілля й моніторингу грунтового покриву потребує район залізниці.

Під час вивчення рослинного покриву м. Ковеля в умовах урбанізації встановлено, що з-поміж видів трав'яних і деревно-чагарникових рослин паркової зони Ковеля найбільшими концентраторами важких металів є терен колючий (Prunus spinosa L.), верба біла (Salix alba L.) та клен-явір (Acer pseudoplatanus L.), водночас береза повисла (Betula pendula Roth.), липа серцелиста (Tilia cordata Mill.) i тонконіг звичайний (Poa trivialis L.) - найменшими. Ці результати свідчать, що види-накопичувачі можна використати як для фітоіндикації, так і з метою найкращого очищення атмосферного повітря від забруднень.

За вмістом важких металів у листках різних видів рослин нами побудовано низхідні ряди, які вказують на найбільший уміст у них таких елементів, як марганець, цинк і мідь. Аналіз кореляцій між умістом важких металів у рослинах паркової зони й грунтах показав, що лише береза повисла має тісний прямий зв'язок умісту елементів у листках і в грунті.

Таблиия 2

Коефіціснти кореляції між умістом досліджених важких металів у грунті та листках (або зеленій масі) рослин

\begin{tabular}{|l|c|}
\hline \multicolumn{1}{|c|}{ Рослина } & Коефіціснт парної кореляції \\
\hline Betula pendula Roth. & $\mathbf{0 , 9 7 *}$ \\
\hline Salix alba L. & 0,74 \\
\hline Carpinus betulus L. & 0,76 \\
\hline Tilia cordata Mill. & 0,76 \\
\hline Acer pseudoplatanus L. & 0,69 \\
\hline Prunus spinosa L. & 0,74 \\
\hline Poa trivialis L. & 0,74 \\
\hline
\end{tabular}

*Виділено істотно значущуі на 95 \% рівні забезпеченості коефіцієєни кореляиії.

Проведено також кластерний аналіз умісту важких металів у рослинах та грунті паркової зони м. Ковеля. Уміст металів у листках берези повислої увійшов в один кластер з умістом металів у грунтах, що засвідчує можливість використання листків саме цього виду для моніторингу забруднення грунтів.

При визначені коефіцієнта біологічного поглинання (КБП) важких металів із грунту рослинами встановлено найбільші середні значення для кадмію $(2,17)$ і міді $(1,87)$, а найменші - для свинцю $(0,22)$. Найбільші значення суми коефіцієнтів біологічного поглинання зафіксовані для верби білої, терену колючого та клена-явора. При цьому визначені види 3 максимальними значеннями КБП окремих елементів (табл. 3).

Таблиия 3

Коефіцієнти біологічного поглинання важких металів рослинами паркової зони м. Ковеля

\begin{tabular}{|c|c|c|c|c|c|c|c|}
\hline \multirow{2}{*}{ Вид } & \multicolumn{6}{|c|}{ Важкі метали } & \multirow{2}{*}{$\sum_{\text {кьп }}$} \\
\hline & $\mathbf{P b}$ & $\mathbf{C u}$ & $\mathbf{Z n}$ & Cd & Co & Mn & \\
\hline Betula pendula Roth. & 0,02 & 0,97 & 1,31 & 1,60 & 1,17 & 1,47 & 6,54 \\
\hline Salix alba $\mathrm{L}$. & 0,03 & 2,29 & 0,67 & 4,50 & $\mathbf{1 , 5 8}$ & 0,38 & 9,45 \\
\hline Carpinus betulus L. & 0,01 & 2,19 & 0,41 & 0,80 & 1,0 & 0,41 & 4,82 \\
\hline Tilia cordata Mill. & 0,26 & 1,71 & 0,23 & 1,20 & 0,94 & 0,68 & 5,02 \\
\hline Acer pseudoplatanus L. & 0,32 & 2,1 & 0,23 & 1,70 & 1,41 & 2,96 & 8,72 \\
\hline Prunus spinosa L. & $\mathbf{0 , 8 4}$ & 2,29 & 0,27 & 3,40 & 1,12 & 0,81 & 8,73 \\
\hline Poa trivialis $\mathrm{L}$. & 0,03 & 1,52 & 0,21 & 2,0 & 0,71 & 0,71 & 5,18 \\
\hline КБП (середній уміст) & 0,22 & 1,87 & 0,48 & 2,17 & 1,13 & 1,06 & - \\
\hline
\end{tabular}

Найбільшу акумулятивну здатність щодо свинцю виявляли листки терену колючого, до міді терену колючого та верби білої, до цинку - берези повислої, до кадмію й кобальту - верби білої, до 
марганцю - клена-явора та берези повислої. Верба біла є першою в рейтингу за кількістю металів із найвищим значенням КБП: із шести металів у цього виду найбільші значення в наших дослідженнях установлені для трьох.

Після оцінки ступеня стійкості деревних рослин за життєвим станом у складних урбогенних умовах за показником стану листкових пластинок та крони досліджені види можна розмістити від найстійкішого до нестійкого в такій послідовності: Picea abies (L.) Karst > Alnus glutinosa (L.) Gaerth $>$ Betula pendula Roth. > Fraxinus excelsior L. > Acer platanoides L. > Robinia pseudoacacia L. $\geq$ Sorbus aucuparia L. > Salix acutifolia Willd. > Juglans regia L. > Populus alba L. > Populus italica (DuRoi) Moench > Tilia cordata Mill. $\geq$ Tilia platyphyllos Scop. > Aesculus hippocastanum L. ( табл. 4).

Таблиия 4

\section{Оцінка стану листкової поверхні та крони деревних рослин у вуличних насадженнях промзони м. Ковеля, $n=10$}

\begin{tabular}{|c|c|c|c|c|c|}
\hline Вид & $\begin{array}{l}\text { Живі гілки } \\
\text { в кроні, \% }\end{array}$ & $\begin{array}{l}\text { Облиснені } \\
\text { гілки, \% }\end{array}$ & $\begin{array}{c}\text { Живе } \\
\text { (без } \\
\text { некрозів) } \\
\text { листя, \% }\end{array}$ & $\begin{array}{c}\text { Жива площа } \\
\text { листка } \\
\text { (середня), \% }\end{array}$ & $\begin{array}{c}\text { Сумарна } \\
\text { оцінка, } \\
\text { балів }\end{array}$ \\
\hline Ялина звичайна Picea abies (L.) Karst & $95,0 \pm 4,37$ & $94,2 \pm 4,43$ & $94,4 \pm 4,72$ & $95,2 \pm 4,47$ & 37,9 \\
\hline $\begin{array}{l}\text { Вільха клейка, чорна Alnus glutinosa (L.) } \\
\text { Gaerth }\end{array}$ & $93,8 \pm 4,5$ & $92,4 \pm 4,62$ & $88,5 \pm 4,51$ & $93,4 \pm 4,30$ & 36,8 \\
\hline Береза повисла Betula pendula Roth. & $93,0 \pm 4,28$ & $91,7 \pm 4,31$ & $87,4 \pm 6,11$ & $92,0 \pm 5,70$ & 36,4 \\
\hline Ясен звичайний Fraxinus excelsior L. & $93,4 \pm 4,48$ & $91,3 \pm 4,20$ & $86,8 \pm 4,34$ & $89,5 \pm 5,46$ & 36,1 \\
\hline Клен гостролистий Acer platanoides L. & $93,0 \pm 4,56$ & $92,1 \pm 4,70$ & $84,0 \pm 5,21$ & $89,0 \pm 4,45$ & 35,8 \\
\hline Робінія звичайна Robinia pseudoacacia L & $92,1 \pm 4,33$ & $91,3 \pm 4,47$ & $76,7 \pm 3,84$ & $86,3 \pm 6,04$ & 34,6 \\
\hline Горобина звичайна Sorbus aucuparia L. & $92,5 \pm 4,72$ & $91,0 \pm 4,46$ & $77,1 \pm 3,93$ & $85,1 \pm 4,60$ & 34,5 \\
\hline Верба гостролиста Salix acutifolia Willd. & $91,7 \pm 4,40$ & $90,7 \pm 4,27$ & $75,2 \pm 4,74$ & $84,9 \pm 5,18$ & 34,2 \\
\hline Горіх грецький Juglans regia L. & $91,1 \pm 4,46$ & $90,2 \pm 4,60$ & $73,4 \pm 5,29$ & $84,0 \pm 5,46$ & 33,9 \\
\hline Тополя біла Populus alba L. & $90,4 \pm 4,88$ & $90,5 \pm 4,34$ & $64,7 \pm 3,36$ & $70,8 \pm 4,11$ & 31,6 \\
\hline $\begin{array}{l}\text { Тополя пірамідальна Populus italica } \\
\text { (DuRoi) Moench }\end{array}$ & 90 & 91 & 2,95 & $=5,05$ & 31,3 \\
\hline Липа серцелиста Tilia cordata Mill. & $75,0 \pm 3,75$ & $70,5 \pm 3,17$ & $58,1 \pm 3,02$ & $64,0 \pm 3,26$ & 26,8 \\
\hline Липа широколиста Tilia platyphyllos Scop & $78,2 \pm 3,68$ & $75,0 \pm 3,76$ & $50,1 \pm 2,66$ & $63,1 \pm 3,41$ & 26,6 \\
\hline $\begin{array}{l}\text { Гіркокаштан звичайний Aesculus } \\
\text { hippocastanum L. }\end{array}$ & $68,1 \pm 3,07$ & $60,4 \pm 2,90$ & $29,7 \pm 1,49$ & $42,1 \pm 2,02$ & 20,0 \\
\hline
\end{tabular}

Отже, найстійкішою деревною рослиною в промисловій зоні м. Ковеля є ялина звичайна (Picea abies (L.) Karst), а найменш стійкою - гіркокаштан звичайний (Aesculus hippocastanum L.). Іншими науковцями також установлено найнижчий рівень стійкості гіркокаштану звичайного, порівняно 3 іншими видами деревних рослин, для різних урбоекосистем України [2].

Життєвість зелених насаджень м. Ковеля залежить від комплексного урбогенного градієнта середовища, до якого входять характерні особливості едафотопу, кліматопу й забруднення довкілля полютантами. I чим більший вплив урбогенних факторів, тим більш ослаблені дерева. Зелені насадження в ареалах із високим рівнем забруднення перебувають у значно гіршому стані, ніж рослинність із менш забрудненої території, що, безумовно, пов'язано з погіршенням умов зростання [7].

Висновки та перспективи подальшого дослідження. Грунти урбоекосистеми міста Ковеля 3 плином часу істотно антропогенно змінені за основними агрохімічними показниками: відбулося достовірне збільшення числа $\mathrm{pH}$ (алкалізація середовища), умісту фосфору та калію, що, зі свого боку, вагомо впливає на акумулятивну здатність грунтового покриву. 3'ясовано істотне збільшення вмісту важких металів у грунтах урбоекосистеми Ковеля (окрім марганцю), порівняно з фоновими показниками. Показано, що свинець і мідь локально присутні в грунтах Ковеля в концентраціях, які в гумусово-елювіальному горизонті в декілька разів перевищують ГДК, а цинк, кадмій і кобальт істотно перевищують лише природний фон, у рослинах найбільше концентруються марганець, цинк і мідь. 
За зменшенням ступеня забруднення досліджені об'єкти утворюють ряд: залізниця > парк ім. Т. Г. Шевченка > вул. Т. Боровця > АЗС > вул. Заводська, тому грунтовий покрив району, прилеглого до залізниці, потребує невідкладної інженерної рекультивації, ремедіації й фітомеліорації. У зелених насадженнях м. Ковеля істотно ослаблюється життєвість деревних рослин за низкою індикативних морфологічних змін. Найстійкішими деревними видами в промисловій зоні Ковеля є ялина звичайна, вільха клейка, береза повисла, ясен звичайний, клен гостролистий, а найменш стійким виявився гіркокаштан звичайний.

Отже, у результаті проведених досліджень проаналізовано видову різноманітність зелених насаджень м. Ковеля. Уперше науковими спостереженнями доведено, що рослини урбоекосистеми Ковеля під тиском високих концентрацій важких металів у грунтах утрачають життєвість за морфофізіологічними показниками, проте стійкі види (Juglans regia L. та ін.) є ефективними фітомеліорантами, а чутливі (Betula pendula Roth. й ін.) - індикаторами стану довкілля міста. Важливими завданнями $є$ постійний фітосанітарний контроль зелених насаджень, розробка комплексних заходів, спрямованих на підвищення життєвості рослин, і вивчення питання про можливість збагачення урбанізованих ландшафтів новим асортиментом.

\section{Джерела та література}

1. Алексеев Ю. В. Тяжелые металлы в почвах и растениях / Ю. В. Алексеев. - Л. : Агропромиздат, 1987. - 142 с.

2. Головатый С. Е. Тяжелые металлы в агроэкосистемах / С. Е. Головатый. - Минск : Респ. предприятие «Институт почвоведения и агрохимии», 2002. - 240 с.

3. Лысенко Л. Л. Перспективы решения проблемы загрязнения почв тяжелыми металлами / Л. Л. Лысенко, М. И. Пономарев, Б. Ю. Корнилович // Экотехнологии и ресурсосбережение. -2001 . - № 4. C. $58-63$.

4. Мажайский Ю. Ф. Восстановление земель, загрязненных тяжелыми металлами / Ю. Ф. Мажайский // Мелиорация и водное хозяйство. - 2001. - № 2. - С. 34-36.

5. Покровская С. Ф. Регулирование поведения свинца и кадмия в системе почва-растение / С. Ф. Покровская. - М. : [б. и.], 1995. - 52 с.

6. Самохвалова В. Л. Використання антидотів при забрудненні важкими металами системи «грунтрослин» / В. Л. Самохвалова // Екологія та ноосферологія. - 2006. - Т.17, № 1-2. - С. 91-98.

7. Степанок В. В. Влияние сочетания соединений тяжелых металлов на урожай сельскохозяйственных культур и поступление тяжелых металлов в растения / В. В. Степанок // Агрохимия. - 2000. - № 1. C. $74-80$.

8. Черных Н. А. Изменение содержания ряда химических элементов в растениях под действием различных количеств тяжелых металлов в почве / Н. А. Черных // Агрохимия. - 1991. - № 3. - С. 68-76.

9. Antonovics J. Heavy metal tolerance in plants / J. Antonovics, A. D. Bradshow, R. G. Turner // Advances in Ecological Research. - L. ; N. Y. : Academic Press, 1971. - V. 7. - P. 2-86.

Голуб Валентина, Голуб Сергей. Эколого-физиологическая и фитопатологическая оценка растительного покрова г. Ковель в условиях урбанизации. В статье изложены результаты комплексного исследования влияния урбогенных факторов на окружающую среду. Рассматривается пространственная неоднородность загрязнения тяжелыми металлами городских почв с учетом интенсивности источников загрязнения. Исследования подтвердили, что почвы урбоэкосистемы города Ковель с течением времени существенно антропогенно изменены по основным агрохимическим показателям. Исследовано негативное влияние загрязнения токсичными элементами дерново-подзолистых грунтов на рост и развитие зеленых насаждений города Ковеля. Произведена инвентаризация городской растительности и проанализированы морфофизиологические изменения у древесных и травянистых растений, их фенология и биологическая устойчивость в условиях техногенного пресса. Доказано, что самыми устойчивыми древесными видами в промышленной зоне г. Ковеля являются ель обычная, ольха клейкая, береза повислая, ясень обычен, клен остролистый, а менее всего стойким оказался каштан конский. Обосновано и рекомендовано ряд видов растений для уменьшения негативного влияния полютантов на окружающую среду.

Ключевые слова: тяжелые металлы, урбогенные факторы, зеленые насаждения, аккумуляция.

Golub Valentyna, Golub Sergii. Ecological, Physiological and Phytopathological Assessment of Vegetation Under Urbanization Kovel. The article presents the results of a comprehensive study of the impact of urbogennyh factors on the environment. The spatial heterogeneity of urban soil pollution with heavy metals, taking into account the intensity of pollution sources. Studies have confirmed that the soil urboehkosistemy city Kovel over time significantly anthropogenically altered by major agrochemical indexes.Studied the negative impact of pollution with toxic elements sod-podzolic soils on the growth and development of the green spaces of the city of Kovel. It made an inventory of 
urban vegetation and analyzed the morphological and physiological changes in woody and herbaceous plants, their phenology and biological stability in the conditions of anthropogenic press. It is proved that the most resistant wood species in the industrial area of Kovel are common spruce, alder sticky, silver birch, ash, common maple holly, and least of all turned out to be resistant chestnut horse. Substantiated and recommended a number of plant species in order to reduce the negative impact on the environment polyutantov.

Key words: heavy metals, urbogennye factors, green plantations, accumulation.

Стаття надійшла до редколегії 16.02.2016 p.

УДК 631.53.01: 003.13: 582(477-25)

Ірина Швець, Олена Колесніченко

\section{Насіннсва продуктивність рослин Darmera peltata (Torr. ex Benth.) Voss (Saxifragaceae) в умовах міста Кисва}

Наведено результати дослідження особливостей насіннєвої продуктивності рослин Darmera peltata (Torr. ex Benth.) Voss у природних умовах м. Києва. Вивчено біологію цвітіння рослин D. peltata на території колекційної ділянки Ботанічного саду НУБіП України. Здійснено оцінку потенційної й фактичної насіннєвої продуктивності, визначено коефіцієнт насіннєвої продуктивності, виконано морфологічний опис насіння, визначено його масу та розміри.

Ключові слова: Darmera peltata, квітка, плід, насіння, потенційна насіннєва продуктивність, фактична насіннєва продуктивність.

Постановка наукової проблеми та її значення. Вид Darmera peltata (Torr. ex Benth.) Voss єдиний представник роду Дармера (Darmera Voss) родини Ломикаменевих (Saxifragaceae). Природний ареал виду обмежено двома американськими штатами - Каліфорнією та Орегоном (США) [8].

На сьогодні $D$. peltata відома як цінна багаторічна трав'яниста декоративна рослина, що характеризується широким ареалом інтродукції та культивується в багатьох країнах Західної й Північної Європи. Уведення в культуру D. peltata в Україні стримують недостатні відомості про біологічні властивості, онтоморфогенез та репродукційну здатність рослин.

Аналіз досліджень цієї проблеми. В умовах інтродукції міста Києва одним із важливих показників, що характеризує біологічні властивості рослин D. peltata та рівень їх адаптації до нових умов місцезростання, $€$ насіннєва продуктивність. У сучасній ботанічній літературі нами не виявлено публікацій стосовно оцінки насіннєвої продуктивності рослин D. peltata в умовах культури, тому комплексне вивчення цього питання актуальне для розробки наукових основ їх генеративного розмноження.

Мета дослідження - вивчення насіннєвої продуктивності рослин D. peltata в природних умовах міста Києва.

Об’єкт та методика дослідження. Об'єктом дослідження слугували модельні рослини D. peltata на території колекційної ділянки Ботанічного саду НУБіП України м. Києва (далі - БС НУБіП України), розміщеного в південній частині м. Києва на висоті 180 м над рівнем моря. Середня температура повітря протягом року становить $+7,3{ }^{\circ} \mathrm{C}$, найжаркішого місяця (липень) $-+20,0{ }^{\circ} \mathrm{C}$, найхолоднішого (січень) $--5,5^{\circ} \mathrm{C}$. Абсолютний максимум $-+39,4{ }^{\circ} \mathrm{C}$, абсолютний мінімум $--32,2^{\circ} \mathrm{C}$. Сума опадів на рік дорівнює 550-650 мм. Грунти темно-сірі лісові дерново-підзолисті суглинки, багаті на гумус. Дослідження відбувалося протягом 2012-2015 рр. паралельно з фенологічними спостереженнями, які проводили згідно з «Методикою фенологических наблюдений в ботанических садах СССР» [6], рекомендаціями Р. А. Карпісонової [5] та Г. М. Зайцева [4] з певними модифікаціями відповідно до біологічних особливостей росту й розвитку рослин D. peltata.

Визначення насіннєвої продуктивності здійснювали за методикою I. В. Вайнагій $[2,3]$ на основі аналізу таких морфометричних показників, як кількість суцвіть, квіток, плодів, насінних зачатків і насіння.

(C) Швець I., Колесніченко О., 2016 